\title{
Corporate Taxation and Corporate Governance
}

Köthenbürger, Marko; Stimmelmayr, Michael

Publication date:

2009

Document version

Publisher's PDF, also known as Version of record

Citation for published version (APA):

Köthenbürger, M., \& Stimmelmayr, M. (2009). Corporate Taxation and Corporate Governance.

http://www.cesifo-group.de/portal/page/portal/ifoHome/b-publ/b3publwp/_wp_by_number?p_number=2881 


\title{
Corporate Taxation and Corporate Governance
}

\author{
Marko Koethenbuerger \\ Michael Stimmelmayr
}

CESIFO WORKING PAPER NO. 2881

CATEgory 1: Public Finance

DECEMBER 2009

\footnotetext{
An electronic version of the paper may be downloaded

- from the SSRN website:

www.SSRN.com

- from the RePEc website:

- from the CESifo website:

Www.RePEc.org

www.CESifo-group.org/wp
} 


\title{
Corporate Taxation and Corporate Governance
}

\begin{abstract}
The effects of corporate taxation on firm behavior have been extensively discussed in the neoclassical model of firm behavior which abstracts from agency problems. Being central to the corporate governance literature, however, investment behaviour is crucially influenced by diverging interests between shareholders and managers. We set up an agency model and analyze the core issue in corporate taxation of whether the normal return on investment should be exempted from taxation. The findings suggest that the divergence of interests may be intensified and welfare reduced if the corporate tax system exempts the normal return on investment from taxation. The optimal system may well use the full return on investment as a tax base. Hence, tax systems such as an Allowance for Corporate Equity or a cash-flow tax do not have the familiar efficiency-enhancing effects in the presence of corporate agency problems.
\end{abstract}

JEL Code: H25, D21.

Keywords: corporate taxation, corporate governance, allowance for corporate equity, comprehensive business income tax, cash flow tax.

\author{
Marko Koethenbuerger \\ Department of Economics \\ University of Copenhagen \\ Øster Farimagsgade 5 \\ 1353 Copenhagen \\ Denmark \\ marko.koethenbuerger@econ.ku.dk
}

\author{
Michael Stimmelmayr \\ Center for Economic Studies at the \\ University of Munich \\ Schackstrasse 4 \\ 80539 Munich \\ Germany \\ stimmelmayr@Imu.de
}

First version: July 07

This version: November 09

We are grateful to seminar and conference participants in Maastricht (IIPF, 2008), Magdeburg (VfS, 2009), Munich (CES, 2007 and PSE, 2009), and Vienna (WU, 2008) for their helpful comments. In particular, we are grateful for comments by Michael Devereux, Alexander Haupt, Vesa Kanniainen, Marco Runkel, Dirk Schindler, Hans Werner Sinn, Michael Smart and Peter Birch Sorensen. 


\section{Introduction}

The effects of corporate taxation and of capital income taxation on corporate investment have been extensively discussed within the neoclassical model of firm behavior. ${ }^{1}$ The neoclassical framework treats the firm as a "black box", operating so as to maximize the firm value. It thereby disregards tensions between the interests of executives and those of shareholders that are central to the corporate governance literature. This literature rests on the premise that the interests of shareholders and of management are misaligned, and analyzes the role of incentive pay and of the corporate capital structure in limiting the divergence of interests (see Tirole, 2006).

In this paper we try to bridge the gap between these two strands of the literature. We present an agency model of corporate behavior in which we analyze the impact of corporate income taxes on investment decisions and, in a second step, analyze how the tax system can be used as a corrective device. Central to our model, managers and shareholders have diverging objectives due to different perceptions on the desirability of investment projects. Specifically, a manager has the opportunity to invest either in productive investment that yields a pecuniary return, capitalizing in the firm value, or in unproductive investments (pet-projects) that lead to a nonpecuniary return for the manager. The two different investment types cannot be distinguished by the shareholders and the government. Thus, neither an incentive contract between the shareholders and the manager nor the tax system can perfectly control the manager's incentive and, thereby, induce him to invest resources so as to maximize the firm value. As a consequence, managers pay too little dividends compared with a situation where no agency problem exists between shareholders and managers - an implication that is in line with the free cash flow hypothesis of Jensen and Meckling (1976).

We analyze the fundamental question in corporate taxation of whether the normal return on investment should be taxed or whether this should be exempted and, hence, only rents should be taxed. The issue sparks a huge literature in public economics which analyzes the role of immediate write-off provisions for investment expenses (cash-flow tax) or a tax deductibility of the cost of finance (Allowance for Corporate Equity) in exempting the normal return on investment (see, e.g., Auerbach, 2002, and Auerbach et al., 2008, for a review of the literature).

\footnotetext{
${ }^{1}$ See, for instance, King (1974), Auerbach (1979), Bradford (1981), Sinn (1991a) and, for a review of the literature, Auerbach (2002) and Auerbach et al. (2008).
} 
All such policies effectively involve a tax on the marginal return on investment and a subsidy on the marginal cost of investment in equal proportions, thereby taxing only extraordinary returns on investments (rents) and leaving investment choices undistorted. We characterize the efficiency consequences of taxing the normal investment return and, as part of the efficiency effects, we analyze whether the tax treatment of the normal return on investment intensifies or counteracts corporate governance problems. In so doing, we consider tax systems that differ with respect to the tax treatment of the cost of finance. The analysis includes as polar cases two corporate tax systems that have received considerable attention in academic and policy discussion: the Allowance for Corporate Equity $(\mathrm{ACE})^{2}$ and the Comprehensive Business Income Tax (CBIT) ${ }^{3}$. While, as mentioned before, the ACE provides an allowance for corporate equity along with an allowance for the cost of debt financing, the CBIT does not include any allowance. Thereby, the ACE exempts the normal return on investment while the CBIT taxes the full return. ${ }^{4}$

Our main findings are as follows: The agency conflict is intensified if the corporate tax system fully exempts the normal return from taxation. Intuitively, under an ACE both productive and unproductive investments are tax privileged with the consequence that the manager has an incentive to increase the amount of resources invested in both projects. Shareholders do not welcome such a deductibility provision. They prefer less perks and higher dividend pay-outs. Addressing the inefficiency, a government that uses the corporate tax system as a corrective device will not opt for a complete expensing of the cost of finance. It may even find it optimal to eliminate the deductibility rate provided the cost for shareholders in terms of a reduction in productive investment (and hence, dividend payments) is not too pronounced. Otherwise, the government can still preserve the interests of shareholders by reducing the corporate tax rate in combination with a reduction in the deductibility rate. The corporate tax rate has counteracting effects on both types of investment spending. A lower tax rate increases the return on productive investment and thereby strengthens the incentives for productive investment. At the same time, it discourages perk investment because the tax value of the deductibility provision is reduced. Exploiting the asymmetry of investment responses, the government increases welfare by reducing the deductibility rate in combination with a lower statutory corporate tax rate so as to keep the

\footnotetext{
${ }^{2}$ The ACE was first proposed by the Institute of Fiscal Studies (IFS, 1991, and Devereux and Feeman, 1991) and is related to the work by Boadway and Bruce (1984). A refined treatment can be found in, for example, Bond and Devereux (1995).

${ }^{3}$ The CBIT was advocated by the US Treasury (1992).

${ }^{4}$ In our setting an ACE is equivalent to a cash-flow tax. Hence, we refrain from explicitly analyzing this option in exempting the normal return.
} 
effective tax rate on productive investment constant. In sum, agency costs within firms can be reduced and welfare increased by eliminating an ACE, possibly as part of a tax-cut cum basebroadening reform. As such, our results suggest that the normal return on investment should be included in the tax base. We find that the results hold irrespective of how firms finance investments, i.e., whether retained earnings, new equity issue or corporate debt is used as the marginal source of funds.

A frequently mentioned argument against the ACE and in favor of a CBIT is that the latter may lead to higher tax revenues and welfare, most notably when combined with an immediate write-off provision, known as the R-based cash-flow tax (see, e.g., Radulescu and Stimmelmayr, 2007). ${ }^{5}$ Our welfare results rely primarily on adjustments in perk investment and not on adjustments in tax revenues. Also, introducing an immediate write-off in exchange for an ACE would preserve incentives to spend on perks.

The results of this paper have implications for tax policy. Various countries have opted for or consider augmenting the deductibility of debt finance by a similar provision for equity finance. This partly reflects the view that, since a significant fraction of new investments is equity financed through retained earnings, the additional deductibility of the cost of equity finance promotes aggregate investment and growth (see, e.g., Bond, 2000, Auerbach et al., 2008, Griffith et al., 2008, and Devereux and De Mooij, 2009). This paper's findings suggest that the move to an ACE system will increase aggregate investment which, however, may well aggravate corporate agency problems and reduce welfare.

This paper proceeds by providing a literature review in Section 2, followed by a description of the model set-up in Section 3 and of firm investment policy in Section 4. Section 5 presents a welfare analysis and Section 6 considers extensions to the basic set-up. A summary of the main results and some conclusions are presented in Section 7.

\section{Related Literature}

As outlined above, our paper differs from the large body of public finance literature which typically abstracts from the effects of corporate taxes on corporate agency problems (Auerbach, 2002; Hasset and Hubbard, 2002). An early exception is found in Kanniainen and Södersten

\footnotetext{
${ }^{5}$ Absent agency conflicts, an ACE and a CBIT in combination with an immediate write-off provision (R-based cash-flow tax) leaves investment incentives unchanged. The tax base, however, changes because under the R-based cash-flow tax only new investments reduce the tax base, while under an ACE the cost of debt and equity finance lowers the tax base.
} 
(1994) who analyze the impact of bank monitoring on the response of firms to corporate taxes. They take the view that monitoring perfectly solves any conflict between shareholders and the management; hence, agency problems that result in diverging investment incentives are effectively absent in their analysis. Only recently have agency problems made an explicit appearance in tax policy analysis. Desai et al. (2007) show that, when managers can divert resources, corporate taxes interact with the level of investment and rent diversion. ${ }^{6}$ However, they abstract from deductibility provisions related to the cost of finance and a welfare analysis of corporate taxation. $^{7}$

Chetty and Saez (2007) introduce dividend taxes into a model in which, as we assume, managers can use funds either for perks or for productive investments. ${ }^{8}$ Dividend taxes have the same impact on a manager's choices as does equity-based incentive pay. They both influence the share of firm profits that managers and external shareholders receive. Hence, any effects of dividend taxes can be undone by adjustment in the management contract. An interesting implication is that, to the extent that external shareholders can coordinate interests when offering incentive contracts, dividend taxes exert no first-order welfare loss. The efficiency costs only comprise the standard Harberger deadweight burden, despite the pre-existing distortion in investment choices. Put differently, there is no inherent force that guarantees such contract adjustments and, hence, the absence of first-order welfare losses with corporate taxes. In fact, we find that in many reasonable economic environments contract adjustments reinforce the effects of the tax system on investment incentives. The tax system thus not only promotes perks, but also undermines incentives by shareholders (deciding on incentive contracts) to address corporate agency problems. In a revised version of their work, Chetty and Saez also consider the efficiency effects of corporate taxes, but, importantly, do not introduce a deductibility provision for the cost of finance (Chetty and Saez, 2009). ${ }^{9}$ Therein, corporate taxes do not change the incentives to invest in perks and, as a consequence, corporate taxes may not generate first-order

\footnotetext{
${ }^{6}$ In their model the agency problem takes the form of theft rather than empire building as in our paper. Hence, resources leave the firm instead of staying within the firm. From that perspective, the work of Desai et al. (2007) is more targeted to economies with poor corporate governance systems.

${ }^{7}$ Besides corporate taxes, they also consider tax enforcement policies. See also Desai and Dharmapala (2006) and Crocker and Slemrod (2005) on tax enforcement policies when managers and shareholders have misaligned interests

${ }^{8}$ Related contributions on dividend taxation include Gordon and Dietz (2009) and Korinek and Stiglitz (2009). In particular, unlike Gordon and Dietz (2005) and Chetty and Saez (2007), Korinek and Stiglitz assume that managers have a higher discount rate than shareholders. Hence, managers are myopic.

${ }^{9}$ The revised version of the paper came to our knowledge in fall 2009, after this paper had been written. Interestingly, both papers independently adopt the same model for analyzing endogenous incentive contracts.
} 
welfare losses. Part of the difference in results is due to the deductibility of the cost of finance in our model which applies both to productive and non-productive investment. The corporate tax acts like a subsidy on unproductive investment and, hence, creates first-order welfare losses.

Finally, Keuschnigg and Nielsen (2004) focus on a different type of agency problem that particularly applies to start-up firms. Their success probability depends on the effort of both venture capitalists and entrepreneurs. Keuschnigg and Nielsen analyze various tax policies in the presence of the moral hazard problem. For instance, subsidies will in general have different efficiency effects depending on whether they are granted before or after effort decisions are made. Keuschnigg and Ribi (2009) relate the finding to a cash-flow tax and an ACE which inherently differ with respect to the timing of tax reliefs. The cash-flow tax grants it up front when investments are made while the ACE grants a tax relief only when returns are realized. When effort decisions are made in between, only the ACE exerts positive incentive effects. Absent interim decisions, the two tax systems are equivalent in terms of efficiency, and introducing them similarly increases welfare because they relax the entrepreneur's finance constraint. We show that an ACE, and also a cash-flow tax, are generically welfare dominated by tax systems that allow only for limited or no deductibility provisions or, equivalently, immediate write-off provisions. The welfare result is rooted in the managers' taste for perk investment - a preference which is absent in Keuschnigg and Ribi.

\section{Model Set-Up}

Consider a two-period model of corporate investment in which, similar to Chetty and Saez (2007), managers can make two types of investments: productive investments $I$ and unproductive investments (pet-projects) $J$. Initially, the firm has cash holdings $X$ and possibly a positive amount of debt $B$ that can either be paid out as dividends, $D_{1}$, or used for productive investment or for pet-projects. Thus, the firms flow of dividends in period $1, D_{1}$, is

$$
D_{1}=X+B-I-J
$$

In period 2, the firm produces output using the technology $f(I)$ which is strictly increasing and concave in the amount of productive investment. At the end of period 2, the firm is liquidated and all liquidation proceeds net of taxes and liabilities are paid to shareholders. Hence, dividend payments in the second period depend on the firm's net-of-tax profits minus principal and interest 
on debt:

$$
D_{2}=(1-\tau) f(I)+\tau r\left(z_{1} B+z_{2}(K-B)\right)+\tau K-(1+r) B
$$

where $K=I+J$ denotes the aggregate amount of investment and $K-B>0$ is the equity base of the firm (after first-period dividends are paid out). The first term in (2) denotes the net-of-tax return on productive investments $I$. The second term gives the tax savings due to a deductibility of the cost of finance. The variables $z_{1}, z_{2} \in[0,1]$ indicate the extent to which debt interest and the opportunity cost of equity capital are deductible from the corporate tax base. When both tax parameters equal one, debt interest and the opportunity cost of equity are fully tax deductible as is the case under the Allowance for Corporate Equity (ACE) system. If neither of the two cost components are tax deductible, implying $z_{1}=z_{2}=0$, the tax systems resembles the Comprehensive Business Income Tax (CBIT). Most existing tax systems include elements of both polar systems by deducting only the cost of debt finance, i.e. $z_{1}=1$ and $z_{2}=0$. Capital is assumed to fully depreciate after use in production. The third term in (2) represents the tax savings due to capital depreciation. ${ }^{10}$

We consider a mature firm that uses retained earnings to finance both types of investments at the margin. The value of a firm is determined by the present value of all future dividend payments less equity injections. Since a mature firm with excessive cash flow will not issue new equity, the firm value is ${ }^{11}$

$$
V=D_{1}+\frac{D_{2}}{1+r}
$$

where $D_{1}$ and $D_{2}$ are given by (1) and (2), respectively. We do not formally introduce a dividend tax in (3). The results of our paper, however, equally hold in the presence of dividend taxation as long as corporate taxes cannot be fully credited against the shareholder's personal income tax. Tax systems that entail an incomplete offset of corporate taxes at the shareholder level are implemented in a variety of countries, including Germany, the US, and the UK.

\footnotetext{
${ }^{10}$ We abstain from introducing an immediate write-off of investment expenses in period 1. Such a provision can be considered by subtracting the term $z_{3}(I+J)(1+r)$ from the firm's tax base in period 2 . If $z_{3}=1$, the tax system offers a full immediate write-off. An immediate expensing of investment has equivalent effects on investment incentives and on welfare as the deductibility of the cost of investment finance.

${ }^{11}$ Strictly speaking, it is only in the presence of dividend taxation that a mature firm with sufficient cash flows never issues equity and distributes dividends simultaneously (see, e.g., Sinn, 1987, 1991b). Intuitively, a corporation which raises 1 Euro of equity capital and simultaneously pays out 1 Euro as dividends, lowers shareholders' wealth. Shareholders have to pay 1 Euro of new equity, but receive only a net income of $1-\tau^{D}$ Euros when 1 Euro is distributed as dividends by the firm (with $\tau^{D}$ denoting the dividend tax). The reasoning applies in a neoclassical investment model, but also in the agency model adopted here in which the manager owns a share $\alpha>0$ of the firm.
} 
As indicated above, shareholders and the manager have non-congruent investment incentives. In particular, managers either invest productively or unproductively. While productive investments $I$ yield a pecuniary net-of-tax return of $(1-\tau) f(I)$, which capitalizes in firm value, pet projects $J$ solely generate a private benefit $g(J)$ for the manager, where manager utility $g(J)$ is strictly increasing and concave. One may view $J$ as empire-building investments or investments that imply a quiet life for managers. In either case, capital $J$ remains inside the firm and is part of the firm's balance sheet. ${ }^{12}$

Both investments, $I$ and $J$, are non-verifiable, i.e. neither shareholders nor the government is able to verify (at reasonable costs) whether the investments are productive or perks. ${ }^{13}$ This has two implications. First, the tax system cannot distinguish between the two investment types. The deductibility of the cost of finance as well as depreciation applies to both types; see (2). ${ }^{14}$ Secondly, shareholders cannot offer contracts to managers which are conditioned on the level of $J$, ensuring $J=0$. Still, shareholders may use manager compensation contracts as a mechanism to align the incentive of managers and shareholders. ${ }^{15}$ The contract may specify that the manager gets a stake $\alpha \in(0,1)$ in the firm in addition to a fixed wage $a$, which without loss of generality is set to zero in the sequel. ${ }^{16}$ The remaining shares are owned by external shareholders. ${ }^{17}$ These shareholders would like to induce the manager to invest so as to

\footnotetext{
${ }^{12}$ Note, we do not view $J$ as resources that are directly diverted by the manager. We thereby implicitly assume "mature" corporate governance structures to be in place which preclude theft on the part of the manager. See, for instance, Desai et al. (2007) on managers' incentives to divert resources in low-quality governance economies.

${ }^{13}$ This implies that the input-output relation prescribed by $y=f(I)$ is not verifiable such that the inverse $f^{-1}(y)$ cannot be used to contract on $I$.

${ }^{14}$ Alternatively, we could allow that capital does not depreciate or that $I$ and $J$ depreciate at different rates. Still, $I+J$ is part of the balance sheet and the cost of financing $I+J$ is deductible under the corporate income tax, provided $z_{1}, z_{2}>0$.

${ }^{15}$ Corporate debt may equally ameliorate agency problems. Debt effectively mortgages the normal return on investment that must be paid out to debt claimants, thereby reducing the free cash flow available for perks (Jensen, 1986, 1993; Grossman and Hart, 1982). The threat of firm liquidation inherent to debt finance provides similar incentives on perk spending (Aghion and Bolton, 1992; Bolton and Scharfstein, 1996). As a caveat, the incentive device is found to be only partly effective in practice because firms typically have enough cash flow to service debt, thereby leaving some free cash flow to managers (Allen and Gale, 2000). Our results are compatible with the disciplining effect of corporate debt as long as the debt mechanism does not perfectly curb empire-building tendencies, i.e., managers have access to free cash flow at least at the margin.

${ }^{16}$ Manager compensation frequently takes the form of equity-based compensation (either managerial owned stock or stock options); see Murphy (1999). Incentive packages may also include bonus payments associated with higher firm earnings. We omit this type of incentive pay because it is not essential for the results of the paper.

${ }^{17}$ With a risk-neutral manager it is optimal for the shareholders to set $\alpha=1$ in exchange for an up-front payment. The model can be generalized to allow for risky productive investments and risk-averse managers for which $\alpha \in(0,1)$ is generically optimal. We postpone such an analysis to Section 5 in order to present the basic mechanism which renders the tax deductibility of the cost of finance welfare-deteriorating in the simplest possible way.
} 
maximize their wealth

$$
V^{S}=(1-\alpha)\left(D_{1}+\frac{D_{2}}{1+r}\right) .
$$

Noting (1) and (2), the wealth of the shareholders is maximized if managers do not engage in pet projects, $J$, and if they select an investment level $I$ which satisfies

$$
f^{\prime}(I)=\frac{1+r-\left(1+z_{2} r\right) \tau}{1-\tau} .
$$

The investment plan of the firm is still distorted away from the efficient level as long as the tax system does not provide full deductibility of equity cost of finance. If it does $\left(z_{2}=1\right)$, as is the case under an ACE tax system, the investment rule reduces to $f^{\prime}(I)=1+r$.

Agency problems arise when investment decisions are delegated to a manager who chooses productive investments $I$ and pet projects $J$ (and thereby $D_{1}$ and $D_{2}$ ) so as to maximize

$$
V^{M}=\alpha\left(D_{1}+\frac{D_{2}}{1+r}\right)+\frac{g(J)}{1+r},
$$

where dividend payments follow from (1) and (2). The incentive contract influences the manager's objective. A higher equity-based compensation (higher $\alpha$ ) increases the manager's weight attached to firm value relative to private utility. ${ }^{18}$

The timing of events is as follows: In period 1, the management chooses the level of investments $I$ and pet projects $J$. In period 2, production takes place, taxes are collected, shareholders receive dividend payments $D_{2}$, and the manager receives utility $g(J)$. We apply backward induction to solve for a subgame-perfect equilibrium.

\section{Firm Behavior}

The manager maximizes (6) subject to (1) and (2). Investment policy critically depends on whether first-period dividend payments are positive. Provided $D_{1}$ is zero, the first-order condition for $I$ is ${ }^{19}$

$$
\alpha(1-\tau) f^{\prime}(I)=g^{\prime}(X+B-I),
$$

\footnotetext{
${ }^{18}$ Incentive pay (most notably stock options) may lead to perverse manager incentives, taking the form of restating earnings, committing fraud or investing on a short-term rather than long-term perspective at the expense of shareholders (see, e.g., Burns and Kedia, 2006). We may account for the additional agency cost by, for instance, subtracting the leakage term $\alpha \beta$ from the first-period dividend equation (1), where $\beta>0$ measures the intensity of the agency cost associated with incentive pay. The results will stay the same.

${ }^{19}$ External financing due to, for example, new share issue is associated with significant transaction costs which prohibits firms to use new share issue as a regular means to overcome a lack of sufficient internal funds as we assume here. Interestingly, the constrained financing view proves useful in reconciling the extensive margin of firm dividend responses to the 2003 dividend tax cut in the U.S. (see Chetty and Saez, 2009). In Section 5 we extend the analysis to allow firms to issue new shares as well as to use debt finance at no transaction costs.
} 
where $J=X+B-I$ is residually determined. The level of $D_{1}$ is indeed zero if $(1-\tau) f^{\prime}(I)+$ $z_{2} \tau r+\tau>1+r$ holds at the optimum prescribed by (7). Combining (7) with the inequality, the absence of first-period distributions is more likely the lower initial cash holdings $X+B$ or the lower the manager's share in the firm $\alpha$. Following (7), the manager weights the additional second-period dividend payments when investing productively against the loss in private utility from perks. Since the subsidy $z_{2}$ is granted to both investment types, the relative attractiveness of productive and perk investment is not affected by $z_{2}$. Hence, the subsidy leaves investment incentives unchanged and, along with the subsidy $z_{1}$, proportionally capitalizes in firm value.

When dividend payments are positive in all periods, the first-order conditions for the optimal choice of investments, $I$, and pet projects, $J$, are

$$
\begin{array}{lll}
\text { (a) } \frac{\partial V^{M}}{\partial I}: & \alpha\left[-1+\frac{1}{1+r}\left((1-\tau) f^{\prime}(I)+z_{2} \tau r+\tau\right)\right] & =0 \\
\text { (b) } \frac{\partial V^{M}}{\partial J}: & \alpha\left[-1+\frac{1}{1+r}\left(z_{2} \tau r+\tau\right)\right]+\frac{g^{\prime}(J)}{1+r} & =0 .
\end{array}
$$

Productive investment yields an increased dividend payout in period 2 consisting of the netof-tax return on the productive investment and the tax advantage resulting from the deductibility of the cost of equity finance. At the optimum, the marginal benefit equals the loss in dividend payments in period 1 , as shown by the first-order condition (8a). Since the benefits and costs of productive investments fully capitalize in dividend payments, which accrue to the manager and external shareholders in proportions $\alpha$ and $1-\alpha$, the investment incentive of the manager and external shareholders are perfectly aligned. The amount of $I$ coincides with the level preferred by external shareholders; c.f. (5).

Following (8b), the manager invests in pet projects up to the point where the reduction in dividend payments equals the marginal utility of pet projects. The reduction in dividend payment equals the rise in unproductive investment net of tax savings due to the deductibility of the cost of equity finance and the depreciation allowance. As the benefit of perks does not capitalize in the firm value, pet projects create a wedge between the manager's investment incentives and the shareholders' interest. Consequently, the manager pays out too little dividends in order to finance his own projects - a finding that is in line with the free cash flow hypothesis of Jensen and Meckling (1976).

Differentiation of (8a) and (8b) with respect to the corporate tax rate $\tau$ yields

$$
\begin{aligned}
& \text { (a) } \frac{d I}{d \tau}=\frac{f^{\prime}(I)-r z_{2}-1}{(1-\tau) f^{\prime \prime}(I)} \\
& \text { (b) } \frac{d J}{d \tau}=\frac{-\alpha\left(1+r z_{2}\right)}{g^{\prime \prime}(J)}>0 .
\end{aligned}
$$


A rise in the tax rate increases the value of the deductibility provision, while it lowers the net-of-tax return on productive investments. Using (8a) and (9), the latter effect dominates for $z_{2} \in[0,1)$ which signs the investment response (9a) negative. ${ }^{20}$ When $z_{2}=1$, both effects cancel out and the tax rate has no distorting effect on the level of productive investment. A full deducibility provision transforms the corporate income tax into an $\mathrm{ACE}$ which leaves productive investment incentives unaffected (c.f. Boadway and Bruce, 1984; Devereux and Freeman, 1991). A higher tax rate has an unambiguously positive effect on pet projects because the value of the cost deductibility as well as depreciation provision rises. ${ }^{21}$

Differentiating (8a) and (8b) with respect to the deductibility rate $z_{2}$ gives

$$
\begin{array}{ll}
\text { (a) } \frac{d I}{d z_{2}}=-\frac{\tau r}{(1-\tau) f^{\prime \prime}(I)} & >0, \\
\text { (b) } \frac{d J}{d z_{2}}=-\frac{\alpha \tau r}{g^{\prime \prime}(J)} & >0 .
\end{array}
$$

A rise in the deductibility rate, $z_{2}$, promotes spending for both productive investments and pet projects which reflects the higher subsidy on new investments. As to perturbations in the deductibility rate $z_{1}$, we find no effect on investment:

$$
\frac{d I}{d z_{1}}=\frac{d J}{d z_{1}}=0
$$

Intuitively, both investment types are equity financed at the margin, such that a more generous deductibility rate for interest payments leaves investment incentives unaffected, and so only capitalize in the firm value.

\section{Welfare Implications}

Subsequently, we will analyze whether corporate tax policy and, in particular, the choice of the corporate tax base, can be used to ameliorate agency problems in firms. To focus on the corrective role of tax policy we assume that tax revenues are rebated to tax payers as a lump sum. The surplus measure comprises firm value, utility from perks and tax revenues.

The government sets $\tau$ and $z_{2}$ so as to maximize the sum of private welfare (comprising firm value and utility from perks) and discounted tax revenues, anticipating how investment choices

\footnotetext{
${ }^{20}$ Formally, using $(8 \mathrm{a})$ we find $\operatorname{sign}\{d I / d \tau\}=-\operatorname{sign}\left\{1-z_{2}\right\}$.

${ }^{21}$ Fiscal deprecation is not necessary for the result to hold. Even when perks do not fiscally depreciate, as in Chetty and Saez (2009), we cannot avoid the conclusion in our model. Investment outlays (productive and unproductive) are part of the capital stock whose cost of finance is tax deductible.
} 
respond to the tax system. ${ }^{22}$ Formally, using (1) and (2) the government solves

$$
\max _{\tau, z_{2}} \quad X+B-I-J+\frac{f(I)-(1+r) B-T}{1+r}+\frac{g(J)}{1+r}+\frac{T}{1+r},
$$

where

$$
T=\tau\left(f(I)-\left(z_{1} r B+z_{2} r(K-B)\right)-K\right)
$$

and investment responses follow from (7) or (8).

\subsection{No First-Period Dividend Payments}

We first turn to the case in which first-period dividend payments are zero, effectively assuming that $X+B$ is not too large. Using (7) and noting that $d I+d J=0$, the welfare consequence of a tax rate change is

$$
(1-\alpha) \frac{f^{\prime}(I)}{1+r} \frac{d I}{d \tau}+\tau \frac{f^{\prime}(I)}{1+r} \frac{d I}{d \tau}<0 .
$$

Higher corporate taxes lower productive investments and increase perk investments. Thereby, the manager exerts an externality since a fraction of $1-\alpha$ of the reduced second-period dividend income is borne by external shareholders. This creates a first-order welfare effect as captured by the first term. The second term is the familiar Harberger deadweight loss which adjustments in private choices exert on tax revenues. Here, the private decision is the manager's choice of productive investment. The latter drop in response to a higher tax which decreases tax revenues. The Harberger term is proportional to $\tau$ and, hence, is a second-order effect. In total, the welfare costs of the statutory corporate tax are negative, thereby leaving no corrective role for the statutory corporate tax rate.

Following (7), investment behavior is unaffected by the deductibility rate $z_{2}$. The total amount of investment is constant $(d I+d J=0)$ and, since the deductibility provision is granted to both investments, $z_{2}$ does not influence the structure of investment. As such, changes in $z_{2}$ only exert mechanical tax revenue effects, and so the deductibility provision is effectively a lump-sum subsidy. In sum,

Proposition 1: Assume the firm does not pay dividends in the first period. Then, for any level of the corporate tax rate $\tau \in(0,1)$, a full or partial deductibility of the cost of finance,

\footnotetext{
${ }^{22}$ We abstain from a formal representation of the welfare effect of $z_{1}$. Since corporate debt is exogenous and investment levels do not respond to $z_{1}$ the deductibility rate $z_{1}$ is effectively a lump-sum subsidy; entailing no efficiency cost or benefit.
} 
$z_{2} \in(0,1]$, yields the same level of welfare as no tax deductibility, $z_{2}=0$.

Proposition 1 states an equivalence result: Provided all internal funds are used for investments, a tax system that exempts the normal return on investment (such as an ACE or cash-flow $\operatorname{tax}$ ), and a tax system that taxes the full return to investment (CBIT) are equivalent for a given choice of the corporate tax rate. The finding contrasts previous literature which shows that, when interests between managers and shareholders are aligned, a tax exemption on the normal return on investment $\left(z_{2}=1\right)$ increases welfare and, in fact, ensures efficiency of investment choices.

\subsection{First-Period Dividend Payments}

We now consider the case in which first-period dividend payments are positive. Differentiating (12), while accounting for the first-order conditions (8a) and (8b), we get

$$
-(1-\alpha) \frac{d J}{d \tau}+\frac{1}{1+r}\left(\tau\left(f^{\prime}(I)-r z_{2}-1\right) \frac{d I}{d \tau}-\tau\left(r z_{2}+1\right) \frac{d J}{d \tau}\right)<0 .
$$

As captured by the first term, a higher corporate tax has a first-order effect on private welfare. The term reflects the pre-existing distortion in the level of perk investment. By investing in perks the manager exerts a negative externality on external shareholders who bear a fraction $1-\alpha$ of the induced drop in first-period dividend income (rather than second-period income as with $\left.D_{1}=0\right)$. A higher tax increases the tax value of the deductibility provision $z_{2}$ which magnifies the incentive to invest in perks and, thereby, the externality. Unlike perk investments, productive investments do not influence private welfare which follows from an application of the envelope theorem. Recall that incentives to spend on productive investment are aligned between shareholders and the management, while incentives to spend on perks are not aligned. The second term summarizes the behavioral response of the tax base. It reflects the familiar fiscal externality investment choices exert on public revenues. The Harberger term comprises the adjustment in the level of productive investment and perk investment. Following (8a), the term $f^{\prime}(I)-r z_{2}-1$ is positive for $z_{2} \in[0,1)$ and vanishes for $z_{2}=1$. Thus, the response in productive investments generically lowers tax revenues, albeit the government saves on subsidies. As depicted by the second term in brackets, perk investment positively reacts to higher taxes which entitles the firm to higher subsidies and, hence, reduces tax revenues. Combining terms, the overall welfare effect of the tax rate change is strictly negative. Hence, the corporate $\operatorname{tax} \tau$ 
exerts efficiency costs which entails no role for $\tau$ in addressing the agency conflict.

Turning to the welfare effects of the deductibility rate $z_{2}$, we likewise find

$$
-(1-\alpha) \frac{d J}{d z_{2}}+\frac{1}{1+r}\left(\tau\left(f^{\prime}(I)-r z_{2}-1\right) \frac{d I}{d z_{2}}-\tau\left(r z_{2}+1\right) \frac{d J}{d z_{2}}\right) .
$$

As captured by the first term, a higher deductibility rate exerts a negative first-order effect on private welfare, given the pre-existing distortion in the level of perk investment. The second term gives the familiar fiscal externality which a change in investments exerts on public revenues. Similar to the behavioral tax revenue effect of corporate taxes, the tax base response follows from changes in productive and perk investments. Unlike (15), however, the two revenue effects in (16) are of opposite sign. A more generous deductibility provision negatively affects revenues due to the induced rise in perks, but simultaneously expands the tax base through the positive adjustment in productive investment. Taken together, the overall welfare effect of perturbations in $z_{2}$ is ambiguous in sign.

At this point it might be interesting to characterize the optimal choice of $z_{2}$ and $\tau$ in the absence of an agency conflict, i.e. $J \equiv 0$. A higher $z_{2}$ increases productive investment and hence, (16) implies to set $z_{2}=1$. Now, following (8) and (9) the investment response to changes in the tax rate is zero, implying that the first-order condition (15) is zero for any choice of $\tau$. Intuitively, allowing for a full deductibility of the equity cost of finance insulates the return on investment from the tax rate which leaves investment incentives undistorted (Boadway and Bruce, 1984; Devereux and Freeman, 1991). In this case, the efficiency cost of corporate taxation vanishes and the tax rate can be set at any feasible level to collect revenues on rents. In the presence of an agency conflict, the corporate tax is distortionary for any choice of $z_{2} \in[0,1]$; in particular, also for an $\mathrm{ACE}$ system $\left(z_{2}=1\right)$. Intuitively, the aggregate investment level $K=I+J$ is inefficiently high. The manager does not account for the negative effect of perk investment on external shareholders, an effect which is magnified by $\tau$ for all $z_{2} \in[0,1]$.

A cooperative choice of $J$ would result in a lower level of perks. The interesting issue for tax policy design is whether the choice of $z_{2}$ can partially implement a cooperative solution. To infer into the corrective role of $z_{2}$, note that a higher $z_{2}$ exerts counteracting effects on welfare, c.f. (16). Evaluated at $z_{2}=1$, the positive tax base effect due to changes in productive investments is zero since, following (8a), $f^{\prime}(I)-r z_{2}-1=0$ at $z_{2}=1$. This precludes $z_{2}=1$ to be the optimal choice of the deductibility rate. Intuitively, at $z_{2}=1$ the return and cost of productive investment are fully included in the tax base, and so a marginal downward deviation of $z_{2}$ exerts 
no behavioral revenue effect through productive investment. The remaining welfare effects in (16) work through the adjustment in perk investments which are negative in sign. In sum,

Proposition 2: When $D_{1}>0$ and managers have a taste for perk investments, a corporate tax system which allows for a full deductibility of the cost of equity finance $\left(z_{2}=1\right)$ is welfaredominated by a tax system which entails a marginally lower deductibility rate $z_{2}$. The result holds for any level of the corporate tax rate $\tau \in(0,1)$.

Proposition 2 shows that an ACE tax system is not welfare enhancing in the presence of an agency conflict. First, a less generous deductibility provision ameliorates the agency problem between shareholders and the management and, thereby, leads to a first-order welfare gain; c.f. the first term in (16). Second, a tax base broadening limits the negative implications that perk investments have for tax revenues; c.f. the second part of the Harberger term in (16).

Proposition 2 is less informative as to the extent to which $z_{2}$ can be lowered. For $z_{2}<1$, a lower $z_{2}$ continues to have the efficiency benefit of lower perk investment which, however, must now be weighted against the Harberger deadweight loss due to lower productive investment. Provided the productive investment response is not too strong compared with the response in perks, which applies when, for example, the curvature of $f(I)$ is sufficiently pronounced relative to the curvature of $g(J)$, then it will be optimal to set $z_{2}=0 .{ }^{23}$ Otherwise, the optimal choice of the deductibility rate is interior $z_{2} \in(0,1)$, balancing the welfare effects of the two investment types.

Proposition 3: Consider $D_{1}>0$. For any level of the corporate tax rate $\tau \in(0,1)$, the optimal deductibility rate is $z_{2}=0$ provided the reduction in productive investment is not too strong relative to the reduction in perks. Otherwise, the optimal deductibility rate satisfies $z_{2} \in(0,1)$.

Fixing $\tau$, the optimal deductibility rate $z_{2}$ may be positive since a lower $z_{2}$ undermines incentives to invest productively. A straightforward question is whether the undesirable consequence can be addressed by adjustments in the second policy instrument $\tau$. To show that this is possible consider a simultaneous reduction in $z_{2}$ and $\tau$ so as to keep the marginal cost of investing productively constant. The reform leaves incentives to invest productively unaffected, and so only singles out welfare effects that result from corporate agency problems. Following (8), (9)

\footnotetext{
${ }^{23}$ Note from $(10), f^{\prime \prime}(I)$ and $g^{\prime \prime}(J)$ influence the investment responses.
} 
and (10), the policy requires perturbations in $z_{2}$ and $\tau$ to obey $d \tau=\left[\tau(1-\tau) /\left(1-z_{2}\right)\right] d z_{2}$. The associated welfare change is the sum of (15), weighted by $d \tau / d z_{2}$, and of (16). By construction, the behavioral revenue effects related to productive investments (i.e., the first term in brackets in (15), multiplied by $d \tau / d z_{2}$, and in (16)), offset each other and the total change in welfare follows from the change in perks. As a consequence, welfare strictly increases because a less favorable deductibility rate lowers the amount of perk investments, an effect that is reinforced by the drop in the corporate tax rate which reduces the tax value of the deductibility provision. Hence,

Proposition 4: Consider $D_{1}>0$ and a tax system $\left(\tau, z_{2}\right) \in(0,1)^{2}$. When the manager has a taste for perk investment, there always exists a tax-cut cum base-broadening reform (marginally lowering $z_{2}$ and $\tau$ so as to keep productive investment constant) which increases welfare.

Proposition 4 predicts that a marginally lower $z_{2}$ with an appropriate adjustment in $\tau$ increases welfare. By a continuity argument, the tax-cut cum base-broadening reform can be continued until the deductibility provision related to equity finance and, trivially also related to debt finance, is abolished. ${ }^{24}$ Thus, summarizing Propositions 2 to 4 :

Corollary: When managers distribute part of the retained earnings to shareholders and spend some of the remaining amount on perks, then a tax system which fully or partially exempts the normal return on investment from corporate taxation is welfare-dominated by tax system which taxes the full return $\left(z_{1}=z_{2}=0\right)$, possibly at an adjusted corporate tax rate.

Unlike the case when internal funds are only used for investment, in which taxing the normal return is welfare neutral, the Corollary ranks a $\operatorname{CBIT}\left(z_{1}=z_{2}=0\right)$ over an $\operatorname{ACE}\left(z_{1}=z_{2}=1\right)$ in terms of welfare when distributions are made in all periods. The conclusion is different from the finding in the literature which abstracts from agency problems within the firm. Therein,

\footnotetext{
${ }^{24}$ The required post-reform corporate tax rate does not violate the non-negativity constraint. Comparing the effective tax rate on productive investment (5) for $z_{2} \in(0,1)$ and for $z_{2}=0$, the post-reform tax rate $\tilde{\tau}$ which keeps the effective tax rate constant when eliminating $z_{2} \in(0,1)$ is

$$
\tilde{\tau}=\frac{(1+r)(1-\tau)-\left(1+r-\tau\left(r z_{2}+1\right)\right)}{(1-\tau)-\left(1+r-\tau\left(r z_{2}+1\right)\right)},
$$

where $\tau$ is the pre-reform tax rate. Note, we have $\tilde{\tau} \in(0,1)$ when $\tau \in(0,1)$ and $\tilde{\tau}=0$ only when $\tau=0$.
} 
implementing an ACE ensures efficient investment choices and increases welfare.

\subsection{Revenue Implications}

A natural question is whether the implications for tax policy outlined in Propositions 1 to 4 do not undermine the fiscal viability of the public sector by reducing tax revenues. When internal funds are only used for investments, a tax reform that broadens the tax base to include the normal return on investment increases tax revenues, while leaving welfare constant as stipulated by Proposition 1 .

When distributions are made in all periods, tax revenues may still increase following a tax base broadening. As to the reform described in Proposition 2, a small reduction in $z_{2}$ (starting at $z_{2}$ ) broadens the tax base and strictly increases tax revenues, although $I$ and, hence, output decreases. ${ }^{25}$ Further, larger welfare-increasing reductions in $z_{2}$, as implied by Proposition 3 , exert behavioral tax revenue effects. To the extent that these are dominated by the mechanical effect of tax base broadening (as predominantly assumed in the literature on tax reforms entailing a base broadening) tax revenues rise in response.

The reform suggested in Proposition 4 may not necessarily increase tax revenues. The revenue effects depend on the relative importance of the tax cut and the base broadening. We should note that a welfare-increasing tax-cut cum base-broadening reform does not necessitate the tax rate and deductibility rate changes to satisfy $d \tau=\left[\tau(1-\tau) /\left(1-z_{2}\right)\right] d z_{2}$ as assumed above. The tax rate may also be lowered to a smaller extent such that productive investment is slightly reduced. Appealing to a continuity-type argument, welfare still increases in response to a reform that entails a less drastic reduction in $\tau$ than the reduction which is necessary to keep the marginal cost of productive investments constant; c.f. (15) and (16). The alternative tax reform also limits potential revenue shortfalls associated with the aforementioned tax-cut cum base-broadening reform.

\section{Extensions}

In this section we analyze the robustness of our results $(i)$ when firms are cash constrained and resort to external financing and $(i i)$ when incentive contracts are endogenously determined.

\footnotetext{
${ }^{25}$ Precisely, differentiating (13) with respect to $z_{2}$, inserting (5), and evaluating terms at $z_{2}=1$ (which eliminates the effect of $d I / d z_{2}$ on tax revenues) shows that a marginal drop in $z_{2}$ away from $z_{2}=1$ always generates higher tax revenues.
} 


\subsection{Cash-Constrained Firm}

So far, we have assumed that investments are financed through retained earnings at the margin. We now consider the possibility that investments are financed either through equity issue or through debt.

New Equity Issue When investments are financed by equity issue at the margin, first-period dividend payments are

$$
D_{1}=X+B+E-I-J
$$

where $E$ denotes the amount of new equity issue, and the firm value is given by

$$
D_{1}+\frac{D_{2}}{1+r}-E \text {. }
$$

New shares will only be issued if internal funds $X$ are not sufficient to finance the desired level of investment. Hence, first-period dividend payments are zero (i.e. $X+B+E=I+J$ ) and $d E=d K, K=I+J$, holds at the margin. With dividend payments in the second period given by (2), the manager's investment choice follows from

$$
\max \alpha\left(\frac{(1-\tau) f(I)+\tau r\left(z_{1} B+z_{2}(K-B)\right)+\tau K-(1+r) B}{1+r}-I-J\right)+\frac{g(J)}{1+r} .
$$

Differentiating with respect to $I$ and $J$, one straightforwardly sees that the first-order conditions for $I$ and $J$ coincide with those of a cash-rich firm paying dividends in all periods, c.f. (8a) and (8b), and so do the responses in investment levels to changes in the tax system. Consequently, the welfare analysis of corporate taxes and the deductibility rate $z_{2}$ summarized in Propositions 2 to 4 also apply here. ${ }^{26}$

Corporate Debt Now consider that investments are financed by debt at the margin, i.e. $X+B=I+J\left(D_{1}=0\right)$. Internal funds finance inframarginal investments while debt is used for marginal investments, i.e. $d B=d K, K=I+J$, holds at the margin. ${ }^{27}$

\footnotetext{
${ }^{26}$ At this point we should note that the equivalence of investment incentives of a cash-rich and a cash-constrained firm, which resorts to new share issue to finance new investment, no longer holds when dividend taxes are explicitly considered. Unlike the case of a cash-rich firm, the source of funds and the use of funds are differently treated by the dividend tax. Dividend taxes only apply to the latter which in itself creates a distortion (e.g., Auerbach, 2002). However, accounting for dividend taxes would not change the qualitative finding. In detail, consider dividends are taxed at rate $\tau^{D}$ and that corporate taxes cannot fully be credited against dividend taxes. Now substitute the statutory corporate tax rate $\tau$ by the corporate tax rate $\tau^{*} \leq \tau$, which applies after corporate taxes have been credited, and rewrite $\left(1-\tau^{D}\right) /(1+r)=1 /(1+\bar{r})$ in all equations. The basic reasoning underlying Propositions 2 to 4 continues to apply in the augmented setting.

${ }^{27}$ We tie corporate debt changes to investment changes and, thereby, exclude the possibility that equity is substituted for debt given investment $K$. One may think of this financial constraint as being imposed by external
} 
With debt as the marginal source of funds, dividend payments in the second period are

$$
D_{2}=(1-\tau) f(I)+\tau r\left(z_{1}(K-X)+z_{2} X\right)+\tau K-(1+r)(K-X)
$$

where $K-X>0$ is the level of corporate debt. Following (6), the management chooses $I$ and $J$ so as to maximize

$$
V^{M}=\alpha\left(\frac{D_{2}}{1+r}\right)+\frac{g(J)}{1+r}
$$

Noting (20), the first-order conditions are

$$
\begin{array}{lll}
\text { (a) } \frac{\partial V^{M}}{\partial I}: & \alpha\left[-1+\frac{1}{1+r}\left((1-\tau) f^{\prime}\left(I_{0}\right)+z_{1} \tau r+\tau\right)\right] & =0 \\
\text { (b) } \frac{\partial V^{M}}{\partial J}: & \alpha\left[-1+\frac{1}{1+r}\left(z_{1} \tau r+\tau\right)\right]+\frac{g^{\prime}(J)}{1+r} & =0 .
\end{array}
$$

Comparing (22) with the first-order conditions (8a) and (8b), investment incentives are qualitatively aligned to those of a cash-rich firm paying dividends in all periods with the exception that the deductibility rate for the cost of debt finance $z_{1}$ rather than for equity finance $z_{2}$ enters the conditions. Hence, replacing $z_{2}$ by $z_{1}$ in the investment responses and the efficiency analysis in Section 5, Propositions 2 to 4 extend to a cash-constrained firm which uses debt finance at the margin.

\subsection{Choice of Incentive Contract}

A straightforward question is whether our findings will disappear once we account for the endogeneity of the sharing parameter $\alpha$. To answer the question, we extend the basic model in two directions: first the manager is risk averse and, second, production is stochastic. In this environment, the shareholders' choice of $\alpha$ follows from a well-known incentive-insurance trade-off (e.g., Holmstrom, 1979). A higher $\alpha$ undermines incentives to invest in perks, but at the same time exposes the manager to more risk. The former effect is welcome by shareholders, while the latter is costly to shareholders since it requires a higher compensatory lump-sum wage payment to the manager. We relegate the formal analysis of contract choice to the appendix and only briefly summarize the relevant findings in this section.

When internal funds are exclusively used for investment, the choice of the sharing parameter $\alpha$ turns out to be independent of $z_{2}$. Hence, changes in $z_{2}$ exert no behavioral response in the

creditors to ensure that debt is used for investment rather than for immediate dividend pay-outs. Tax-induced incentives for equity-debt substitution do not exist when $z_{1}=z_{2}$, a finding which is familiar from neoclassical investment models. The paper's findings remain intact subject to the qualification that $z_{1}=z_{2}$ always holds and, hence, that the identified tax reforms entail proportional changes in the deductibility rates. The formal analysis is available upon request. 
two types of investment and the sharing parameter. As such, $z_{2}$ is a lump-sum subsidy and the result in Proposition 1 extends to the augmented setting of endogenous contracts.

When distributions are made in all periods, the optimal sharing parameter $\alpha$ depends on the two tax variables $\tau$ and $z_{2}$ and, in particular, is unambiguously related to them. As one may expect, a higher $\tau$ or $z_{2}$ increases perks and the optimal adjustment in the contract may be to increase $\alpha$ to counteract the disincentive effect. However, the tax parameters and $\alpha$ may well become substitutes. Intuitively, a rise in $\tau$ or $z_{2}$ makes a reduction in perks initiated by a higher $\alpha$ more costly to shareholders due to the larger loss in subsidy payments and, as a consequence, the sharing parameter may drop in response. We find that the latter effect dominates in many economically reasonable environments. For instance, a higher tax parameter $z_{2}$ lowers $\alpha$ when $g^{\prime}(J)$ not too concave. The condition is satisfied for a wide class of preferences, including CobbDouglas, iso-elastic, and exponential preferences. ${ }^{28}$

Changes in perk investment are the source of welfare gains of the tax reforms outlined in Propositions 2 to 4 . Endogenous contracts exert an additional effect on perk investment:

$$
\frac{d J}{d i}=\underbrace{\frac{\partial J}{\partial i}}_{+}+\underbrace{\frac{\partial J}{\partial \alpha}}_{-} \frac{d \alpha}{d i}, \quad i=\tau, z_{2} .
$$

The first term is the direct effect of tax parameters on perks given $\alpha$, while the second term gives the indirect effect through the adjustment in contract choice. The tax system always promotes incentives to invest in perks when the two tax parameters and $\alpha$ are substitutes or unrelated, $d \alpha / d i \leq 0$ which holds for a wide range of preference functions. Otherwise, a more generous tax subsidy $\tau z_{2}$ increases perks iff the direct effect is not completely undone by adjustments in the incentive contract.

Propositions 2 and 3 continue to hold with endogenous contracts when the tax system has a distortionary effect on $J$ on net, i.e. the investment response (23) is positive. ${ }^{29}$ Under the same condition, the finding in Proposition 4 continues to hold provided the manager is not too risk averse. The reason is that with risk-averse managers the tax system provides insurance to the manager. The corporate tax rate absorbs part of the fluctuations in the return to productive investment which lowers the variance of the manager's income. A tax-cut cum base-broadening reform hence exposes the manager to more risk. ${ }^{30}$ Summing up:

\footnotetext{
${ }^{28}$ For these preference functions $g^{\prime}(J)$ is convex, i.e. $g^{\prime \prime \prime}(J)>0$.

${ }^{29}$ In fact, (23) is only required to hold for perturbations in the deductibility rate $z_{2}$. See the Appendix.

${ }^{30}$ To the extent that managers privately insure against idiosyncratic shocks by holding a diversified portfolio,
} 
Proposition 5: With an endogenous choice of incentive contracts, Proposition 1 continues to hold. Propositions 2 and 3 continue to apply provided contract choices do not nullify the effect of the tax system on perk investment. Additionally, Proposition 4 holds if contracts do not nullify the tax effect on perks and the manager is not too risk averse.

We should note that the conditions are only sufficient for the welfare results in Propositions 2 to 4 to extend to the case of endogenous incentive contracts; see the Appendix. Finally, it is straightforward to show that the findings in Proposition 5 also apply to a cash-constrained firm that resorts to either equity issue or debt finance as the marginal source of funds.

\section{Discussion and Concluding Remarks}

This paper analyzes the question of whether corporate taxes should exempt the normal return on investment from taxation as entailed by, for instance, an ACE system and a cash-flow tax. The issue sparks a huge body of literature which predominantly abstracts from corporate agency problems. Unlike previous literature, we allow for a conflict of interest between shareholders and the management. Investments may take two forms: They are either productive and, thereby, enhance the firm value, or they are purely dissipative from the shareholders' perspective, but utility-enhancing from the manager's perspective. We analyze how the tax treatment of the normal investment return affects investment incentives, firm value, and welfare. The main result of our analysis is that a government that is interested in correcting the agency conflict will generically not fully exempt the normal return from taxation and may well tax it at the same rate as above-normal returns. The result is informative for the tax policy discussion in many countries that have introduced or consider introducing an ACE (see, e.g., Devereux and De Mooij, 2009). The implication of the analysis is that a switch to an ACE system increases investment, but may well aggravate corporate agency problems and reduce welfare.

In our analysis firms have an identical marginal source of finance. In practice, firms are heterogeneous with respect to their financing behavior and the question arises as to relevance of our findings with heterogeneous corporate finance patterns. Our basic finding that an ACE tax system is not welfare optimal holds independently of the marginal source of funds. For

they may not significantly be affected by an increased risk-exposure. See, for instance, Slemrod (2004) for a related reasoning when agency problems intertwine with corporate tax evasion. 
a firm that uses equity finance at the margin, a lower deductibility rate for equity cost $z_{2}$ generates an efficiency gain while a lower rate applicable to the cost of debt $z_{1}$ implies a lumpsum redistribution between the private and the public sector (and vice versa for firms that rely on debt as the marginal source of finance). A simultaneous reduction in the two deductibility rates, possibly combined with a reduction in the tax rate so as to keep the level of productive investments constant, increases welfare in the extended environment.

Our analysis is partial equilibrium. We are confident that the results equally apply to a general equilibrium model of a closed economy as the surplus gain of the aforementioned reforms will allow for higher levels of household utility in aggregate. Additional effects become important in an open economy. First, with capital mobility source-based capital taxes discourage domestic investment and lower wage income. Previous literature shows that exempting the normal return on investment increases investment and, potentially even insulates domestic tax policy from capital mobility (see Griffith et al., 2008). ${ }^{31}$ Most notably, our results imply that when an ACE system insulates domestic tax policy from capital mobility in a neoclassical investment model, this conclusion may no longer apply in an agency model. The reason is that, with an ACE system, a higher statutory tax rate leaves productive investment choices unchanged, but increases perk investment and, thereby, reduces the rate of return investors earn. Their response will be to withdraw some of the capital from the tax-raising country. Thus, even when only above-normal returns are subject to corporate taxation, the marginal cost of public funds will generically be upward distorted by capital mobility. Governments may want to limit the degree to which the normal return is exempted from taxation in order to counteract the perk-induced outflow of capital.

Second, the national government may not be interested in accounting for total firm value in its welfare measure. To the extent that firms are owned by foreigners, national governments have an interest in exporting part of the tax burden onto foreigners (e.g., Huizinga and Nielsen, 1997). From that perspective, our analysis may be interpreted as the cooperative solution among national governments. However, uncoordinated policy choices do not overturn the relevance of our findings. For instance, Propositions 1 to 4 continue to hold in the presence of unilateral policy-making provided the domestically owned share of the firm is not too small. A further change in the welfare analysis may be due to the existence of multinational enterprises (MNE).

\footnotetext{
${ }^{31}$ The latter conclusion applies, for instance, in Zodrow-Mieszkowski-type tax competition models in which capital flows only respond to marginal tax rates (Zodrow and Mieszkowski, 1986).
} 
An inefficiency which arises in the presence of MNE is related to strategic transfer pricing which is guided by statutory tax rate differentials across countries (e.g., Haufler and Schjelderup, 2000). The governments' incentives to lower the statutory tax rates make the tax-cut cum base-broadening reform mentioned in Proposition 4 more attractive. The reform shifts more book profits to the reform country which tends to strengthen incentives to adopt the reform unilaterally. Albeit being interesting, we leave a formal analysis of these issues (along with a treatment of agency problems within MNE) to future research. 


\section{A Endogenous Choice of $\alpha$ with Risk-Averse Managers}

Consider a moral hazard model in the spirit of Holmstrom (1979). There is a continuum of firms which are ex-ante identical, but differ ex-post w.r.t. output. In particular, production is stochastic and takes the form $F(I)=f(I)+\epsilon$ where $f(I)$ is the deterministic part of production and $\epsilon$ is a stochastic term. The latter represents an idiosyncratic shock to production which satisfies $E(\epsilon)=0$ and $\operatorname{Var}(\epsilon)=\sigma^{2}$. The shock to production is only realized after investment choices have been made.

The manager is risk averse with mean-variance preferences

$$
U=E(w)-\rho \operatorname{Var}(w)+\frac{g(J)}{1+r}, \quad \rho>0 .
$$

$w$ denotes the incentive contract which comprises an equity-based component and a lump-sum payment $a .^{32}$ In discounted value, the compensation is

$$
w=\alpha\left(D_{1}+\frac{D_{2}}{1+r}\right)+\frac{a}{1+r} .
$$

Dividend payments in the second period are

$$
D_{2}=(1-\tau) F(I)+\tau r\left(z_{1} B+z_{2} K\right)+\tau K-a-(1+r) B .
$$

Using (1), the expected value and the variance of the wage payment is

$E(w)=\alpha\left(X+B-I-J+\frac{1}{1+r}\left((1-\tau) f(I)+\tau r z_{1} B+\tau\left(r z_{2}+1\right) K-a-(1+r) B\right)\right)+\frac{a}{1+r}$

and

$$
\operatorname{Var}(w)=\left(\alpha \frac{1-\tau}{1+r}\right)^{2} \sigma^{2}
$$

The timing of events is as follows: At the beginning of period 1 external shareholders choose the incentive contract. The hired manager chooses the level of investments $I$ and pet projects $J$ afterwards. In period 2, the production shock is realized, production takes place, taxes are collected, shareholders receive dividend payments $D_{2}$, and the manager receives utility $g(J)$. We apply backward induction to solve for a subgame-perfect equilibrium.

The manager maximizes utility (24) subject to (27) and (28). Straightforwardly, since the variance of the wage rate is constant from the perspective of the manager, investment choices

\footnotetext{
${ }^{32}$ If utility over money is exponential and if the error term $\epsilon$ is normally distributed, then expected utility can be represented in mean-variance form without loss of generality.
} 
are the same as with deterministic production. Hence, investment levels follow from (8a) and $(8 \mathrm{~b})$.

The manager's outside option is normalized at zero. Using the manager's participation constraint $U=0$, expected shareholder income is

$$
E\left((1-\alpha)\left(D_{1}+\frac{D_{2}}{1+r}\right)\right)=E\left(D_{1}+\frac{D_{2}}{1+r}\right)+\frac{a}{1+r}-\rho\left(\alpha \frac{1-\tau}{1+r}\right)^{2} \sigma^{2}+\frac{g(J)}{1+r}
$$

No First-Period Dividend Payments Assuming $D_{1}=0$ and invoking the envelope theorem, the first-order condition for the choice of $\alpha$ is

$$
\frac{(1-\tau) f^{\prime}(I)}{1+r} \frac{d I}{d \alpha}=2 \alpha \rho\left(\frac{1-\tau}{1+r}\right)^{2} \sigma^{2}
$$

Following (7), the investment choice is unaffected by $z_{2}$ and so is the choice of $\alpha$. We can conclude that perturbations in $z_{2}$ exert no behavioral responses and so only imply a lump-sum redistribution between the private and the public sector. As such, Proposition 1 extends to the case of endogenous incentive contracts.

First-Period Dividend Payments Assuming $D_{1}>0$ and invoking the envelope theorem, the first-order condition for the choice of $\alpha$ is

$$
\left(-1+\frac{1}{1+r}\left(\tau r z_{2}+\tau\right)+\frac{g^{\prime}(J)}{1+r}\right) \frac{d J}{d \alpha}=2 \rho \alpha\left(\frac{1-\tau}{1+r}\right)^{2} \sigma^{2}
$$

which implicitly defines $\alpha$ as a function of the tax parameters $\tau$ and $z_{2}$. Differentiating (31) yields

$$
\begin{aligned}
\frac{d \alpha}{d \tau} & =\left\{\left(\frac{z_{2} r+1}{1+r}+\frac{g^{\prime \prime}(J)}{1+r} \frac{\partial J}{\partial \tau}\right) \frac{\partial J}{\partial \alpha}+\left(-1+\frac{1}{1+r}\left(\tau r z_{2}+\tau\right)+\frac{g^{\prime}(J)}{1+r}\right) \frac{\partial^{2} J}{\partial \alpha \partial \tau}\right. \\
& \left.+4 \rho \alpha \frac{1-\tau}{(1+r)^{2}} \sigma^{2}\right\} \Delta^{-1} \\
\frac{d \alpha}{d z_{2}} & =\left\{\left(\frac{\tau r}{1+r}+\frac{g^{\prime \prime}(J)}{1+r} \frac{\partial J}{\partial z_{2}}\right) \frac{\partial J}{\partial \alpha}+\left(-1+\frac{1}{1+r}\left(\tau r z_{2}+\tau\right)+\frac{g^{\prime}(J)}{1+r}\right) \frac{\partial^{2} J}{\partial \alpha \partial z_{2}}\right\} \Delta^{-1}
\end{aligned}
$$

where $\Delta>0$ holds by the second-order condition. Using (8) to substitute for $\partial J / \partial \tau$ and $\partial J / \partial z_{2}$, respectively, the first bracketed term on the right-hand side of (32) and (33) is positive. Next, from (8b) we can compute

$$
\frac{\partial^{2} J}{\partial \alpha \partial \tau}=\frac{z_{2} r+1}{1+r}\left(\frac{-g^{\prime \prime}(J)}{1+r}\right)^{-1}-\left(-1+\frac{\tau r z_{2}+\tau}{1+r}\right)\left(\frac{-g^{\prime \prime}(J)}{1+r}\right)^{-2} \frac{g^{\prime \prime \prime}(J)}{1+r} \frac{\partial J}{\partial \tau}
$$


and

$$
\frac{\partial^{2} J}{\partial \alpha \partial z_{2}}=\frac{\tau r}{1+r}\left(\frac{-g^{\prime \prime}(J)}{1+r}\right)^{-1}-\left(-1+\frac{\tau r z_{2}+\tau}{1+r}\right)\left(\frac{-g^{\prime \prime}(J)}{1+r}\right)^{-2} \frac{g^{\prime \prime \prime}(J)}{1+r} \frac{\partial J}{\partial z_{2}} .
$$

Both cross derivatives are positive when $g^{\prime \prime \prime}(J)$ is not too negative. Noting that $-1+\frac{1}{1+r}\left(\tau r z_{2}+\right.$ $\tau)<0$ and $\partial J / \partial \alpha<0$, we have $d \alpha / d z_{2}<0$ when $g^{\prime \prime \prime}(J)$ is not too negative - a condition which holds for a wide class of preference functions including Cobb-Douglas, iso-elastic, and exponential preferences (for which $g^{\prime \prime \prime}(J)>0$ ). Additionally, we have $d \alpha / d \tau<0$ provided the aforementioned condition holds and the insurance term (last term in (32)) is not too large.

Welfare is given by the sum of shareholder income, manager utility, and tax revenues:

$$
E\left((1-\alpha)\left(D_{1}+\frac{D_{2}}{1+r}\right)\right)+U+\frac{E(T)}{1+r},
$$

where expected tax revenues are given by (13). Inserting the participation constraint $U=0$, to eliminate $U$ and $\alpha$, yields

$$
E\left(D_{1}+\frac{D_{2}}{1+r}\right)+\frac{a}{1+r}-\rho\left(\alpha \frac{1-\tau}{1+r}\right)^{2} \sigma^{2}+\frac{g(J)}{1+r}+\frac{E(T)}{1+r} .
$$

Invoking the envelope theorem, the welfare change following a rise in $\tau$ is

$$
\begin{aligned}
& -(1-\alpha) \frac{\partial J}{\partial \tau}+\frac{1}{1+r}\left(\tau\left(f^{\prime}(I)-r z_{2}-1\right) \frac{d I}{d \tau}-\tau\left(r z_{2}+1\right) \frac{\partial J}{\partial \tau}\right) \\
& -\frac{\tau\left(r z_{2}+1\right)}{1+r} \frac{\partial J}{\partial \alpha} \frac{d \alpha}{d \tau}+2 \rho\left(\alpha^{2} \frac{1-\tau}{(1+r)^{2}}\right) \sigma^{2} .
\end{aligned}
$$

The first two terms are familiar from the welfare analysis with an exogenous sharing term $\alpha$, c.f. (15). The endogenous choice of $\alpha$ introduces a new fiscal externality shareholders exert on the public budget through its choice of $\alpha$; see the third term in (38). The effect is only influenced by adjustments in perk investments since productive investment is independent of the sharing parameter - see (8a). From (8b), the response $\partial J / \partial \alpha$ is negative which implies that the change $d \alpha / d \tau$ and the fiscal externality are of equal sign. The last term in (38) represents an insurance effect. A higher corporate tax pools a larger fraction of the idiosyncratic variation in production, and hence in the manager's wage, in the public budget.

The welfare effect of perturbations in $z_{2}$ are

$$
-(1-\alpha) \frac{\partial J}{\partial z_{2}}+\frac{1}{1+r}\left(\tau\left(f^{\prime}(I)-r z_{2}-1\right) \frac{d I}{d z_{2}}-\tau\left(r z_{2}+1\right) \frac{\partial J}{\partial z_{2}}\right)-\frac{\tau\left(r z_{2}+1\right)}{1+r} \frac{\partial J}{\partial \alpha} \frac{d \alpha}{d z_{2}} .
$$

Comparing with (16), the fourth term is new and has the same economic interpretation as its formal analogue in (38). 
To verify whether the main results of the paper remain intact with an endogenous choice of the sharing parameter, it is instructive to sign of the overall welfare effect resulting from changes in perk investment, i.e. the first and third term in (38) and (39). Provided $d \alpha / d i, i=\tau, z_{2}$, is negative, the overall effect is negative. Differently, when the response in $\alpha$ is positive, both terms are of opposite sign. The overall effect can still be signed under a regularity condition, i.e., when the direct effect of a rise in the tax parameter on $J$ dominates the indirect effect which works via the adjustment in $\alpha$. Formally, combining the first and third term and inserting $(8 \mathrm{~b})$ gives

$$
-(1-\alpha) \frac{\partial J}{\partial i}-\frac{\tau\left(r z_{2}+1\right)}{1+r} \frac{\partial J}{\partial i}-\frac{\tau\left(r z_{2}+1\right)}{1+r} \frac{\partial J}{\partial \alpha} \frac{d \alpha}{d i}, \quad i=\tau, z_{2} .
$$

Provided the overall investment response satisfies

$$
\frac{d J}{d i}>0 \quad \Leftrightarrow \quad \frac{\partial J}{\partial i}>\left|\frac{\partial J}{\partial \alpha}\right| \frac{d \alpha}{d i}, \quad i=\tau, z_{2}
$$

the effect of $J$ on welfare is negative. Note, the condition is only a sufficient condition. Even in its absence, (40) may still be negative.

The results in the main part of the paper stay intact when, for instance, the overall investment response $d J / d i$ is positive (which is a sufficient condition). For $z_{2}=1$ the second term (39) is zero. A marginal reduction in $z_{2}$, hence, increases welfare which is the result we state in Proposition 2 and, as stipulated by Proposition 3, larger reductions in $z_{2}$ increase welfare provided the drop in productive investments is not too strong relative to the drop in perk investments. For $z_{2} \in(0,1)$, we can always construct a tax-cut cum base-broadening reform (lower $z_{2}$ and $\tau$ ) so as to leave productive investment unaffected. Welfare increases due to the reduction in $J$, but decreases due to a lower insurance of the manger via the tax system. Provided, for instance, the manager's risk aversion (as captured by $\rho$ ) or the shock variance $\sigma^{2}$ is not too large, overall welfare increases. This is akin to the result we state in Proposition 4.

\section{References}

[1] Aghion, P. and P. Bolton (1992), An incomplete contract approach to financial contracting, Review of Economic Studies, 59, 473-494.

[2] Allen, F. and D. Gale (2000), Governance and competition. in: Vives, X. (Ed.), Corporate Governance: Theoretical and Empirical Perspectives. Cambridge University Press.

[3] Auerbach, A. J. (1979), Wealth maximization and the cost of capital, Quarterly Journal of Economics, 93/3, 433-446. 
[4] Auerbach, A. J. (2002), Taxation and corporate financial policy, in Auerbach, A. J. and M. Feldstein (Eds.), Handbook of Public Economics, Vol. 3, Amsterdam: North-Holland.

[5] Auerbach, A. J., M. P. Devereux and H. Simpson (2008), Taxing corporate income, forthcoming as chapter 9 in The Mirrlees Review: Reforming the Tax System for the 21st Century, to be published by the Institute for Fiscal Studies, London.

[6] Boadway, R. and N. Bruce (1984), A general proposition on the design of a neutral business tax, Journal of Public Economics, 24, 231-239.

[7] Bolton, P. and D. Scharfstein (1996), Optimal debt structure and the number of creditors, Journal of Political Economy, 104, 1-25.

[8] Bond, S. R. (2000), Levelling up or levelling down? Some reflections on the ACE and CBIT proposals, and the future of the corporate tax base, in S. Cnossen (ed.) Taxing Capital Income in the European Union, Oxford: Oxford University Press.

[9] Bond, S. and M.P. Devereux (1995), On the design of a neutral business tax under uncertainty, Journal of Public Economics, 58, 57-71.

[10] Bradford, D. F. (1981), The incidence and allocation effects of a tax on corporate distributions, Journal of Public Economics, 15(1), 1-22.

[11] Burns N. and S. Kedia (2006), The impact of CEO incentives on misreporting, Journal of Financial Economics, 79, 35-67.

[12] Chetty, R. and E. Saez (2007), An agency theory of dividend taxation, NBER Working Paper 13538, Boston.

[13] Chetty, R. and E. Saez (2009), Dividend and corporate taxation in an agency model of the firm, mimeo, University of California, Berkely.

[14] Crocker, K.J. and J. Slemrod (2005), Corporate tax evasion with agency costs, Journal of Public Economics, 89, 1593-1610.

[15] Desai, M., A. Dyck, and L. Zingales (2007), Theft and taxes, Journal of Financial Economics, 84, 591-623.

[16] Desai, M. and D. Dharmapala (2006), Corporate tax avoidance and high-powered incentives, Journal of Financial Economics, 79, 145-179.

[17] Devereux, M.P. and R. De Mooij (2009), An applied analysis of ACE and CBIT reform in the EU, CPB Discussion Paper 128, The Hague.

[18] Devereux, M.P. and H. Freeman (1991), A general neutral profits tax, Fiscal Studies, 12, $1-15$.

[19] Gordon, R. and M. Dietz (2009), Dividends and taxes, in: Auerbach, A. and D. Shaviro (Eds.), Institutional Foundations of Public Finance: Economic and Legal Perspectives, Harvard University Press, Cambrdige, MA. 
[20] Griffith, R., J.R. Hines and P.B. Sørensen (2008), International capital taxation, forthcoming as chapter 10 in The Mirrlees Review: Reforming the Tax System for the 21st Century, to be published by the Institute for Fiscal Studies, London.

[21] Grossman, S.J. and O.D. Hart (1982), Corporate financial structure and managerial incentives, in: McCall, J.J. (Ed.), The Economics of Information and Uncertainty. University of Chicago Press, Chicago, IL.

[22] Hassett, K. and R. Hubbard (2002), Tax policy and investment, in Auerbach, A. J. and M. Feldstein (Eds.), Handbook of Public Economics, Vol. 3, Amsterdam: North-Holland.

[23] Haufler, A. and G. Schjelderup (2000), Corporate tax systems and cross country profit shifting, Oxford Economic Papers, 52, 306-325.

[24] Holmstrom, B. (1979), Observability and moral hazard, Bell Journal of Economics, 10, 74-91.

[25] Huizinga, H. and S.B. Nielsen (1997), Capital income and profit taxation with foreign ownership of firms, Journal of International Economics, 42, 149-165.

[26] Institute for Fiscal Studies (1991), Equity for Companies: A Corporation Tax for the 1990s, London.

[27] Jensen, M.C. (1986), Agency costs of free cash flow, corporate finance, and takeovers, American Economic Review, 76, 323-329.

[28] Jensen, M.C. (1993), The modern industrial revolution, exit, and the failure of internal control systems, Journal of Finance, 48, 831-880.

[29] Jensen, M.C. and W.H. Meckling (1976), Theory of the firm: Managerial behavior, agency costs and ownership structure, Journal of Financial Economics, 3, 305-360.

[30] Kanniainen, V. and J. Södersten (1994), Costs of monitoring and corporate taxation, Journal of Public Economics, 55, 307-321.

[31] Keuschnigg, C. and S.B. Nielsen (2004), Start-ups, venture capitalists, and the capital gains tax, Journal of Public Economics, 88, 1011-1042.

[32] Keuschnigg, C. and E. Ribi (2009), Profit taxation and finance constraints, mimeo, University of St. Gallen.

[33] King, M. (1974), Dividend behaviour and the theory of the firm, Economica, 41, 25-34.

[34] Korinek, A. and J. E. Stiglitz (2009), Dividend taxation and intertemporal tax arbitrage, Journal of Public Economics, 93, 142-159.

[35] Murphy, K. (1999), Executive compensation, in Ashenfelter, O. and D. Card (Eds.), Handbook of Labor Economics, Vol. 3, North-Holland, Amsterdam.

[36] Radulescu, D.M. and M. Stimmelmayr (2007), ACE versus CBIT: Which is better for investment and welfare?, CESifo Economic Studies, 53, 294-328. 
[37] Sinn, H.-W. (1987), Capital Income Taxation and Resource Allocation, North-Holland, Amsterdam.

[38] Sinn, H.-W. (1991a), Taxation and the cost of capital: The 'Old' view, the 'New' view, and Another view, in D. Bradford (Ed.), Tax Policy and the Economy 5, NBER, 25-54.

[39] Sinn, H.-W. (1991b), The vanishing Harberger triangle, Journal of Public Economics, 45, 271-300.

[40] Slemrod, J. (2004), The economics of corporate tax selfishness, National Tax Journal, 4, 877-899.

[41] Tirole, J. (2006), The Theory of Corporate Finance, Princeton University Press, Princeton.

[42] US Department of Treasury (1992), Integration of the Individual and Corporate Tax Systems: Taxing Business Income Once, US Government Printing Office, Washington.

[43] Zodrow, G.R. and P. Mieszkowski (1986), Pigou, Tiebout, property taxation, and the underprovision of local public goods, Journal of Urban Economics, 19, 356-370. 


\section{CESifo Working Paper Series}

for full list see www.cesifo-group.org/wp

(address: Poschingerstr. 5, 81679 Munich, Germany, office@cesifo.de)

2821 Panu Poutvaara and Andreas Wagener, The Political Economy of Conscription, October 2009

2822 Steinar Holden and Åsa Rosén, Discrimination and Employment Protection, October 2009

2823 David G. Mayes, Banking Crisis Resolution Policy - Lessons from Recent Experience Which elements are needed for robust and efficient crisis resolution?, October 2009

2824 Christoph A. Schaltegger, Frank Somogyi and Jan-Egbert Sturm, Tax Competition and Income Sorting: Evidence from the Zurich Metropolitan Area, October 2009

2825 Natasa Bilkic, Thomas Gries and Margarethe Pilichowski, Stay in School or Start Working? - The Human Capital Investment Decision under Uncertainty and Irreversibility, October 2009

2826 Hartmut Egger and Udo Kreickemeier, Worker-Specific Effects of Globalisation, October 2009

2827 Alexander Fink and Thomas Stratmann, Institutionalized Bailouts and Fiscal Policy: The Consequences of Soft Budget Constraints, October 2009

2828 Wolfgang Ochel and Anja Rohwer, Reduction of Employment Protection in Europe: A Comparative Fuzzy-Set Analysis, October 2009

2829 Rainald Borck and Martin Wimbersky, Political Economics of Higher Education Finance, October 2009

2830 Torfinn Harding and Frederick van der Ploeg, Is Norway's Bird-in-Hand Stabilization Fund Prudent Enough? Fiscal Reactions to Hydrocarbon Windfalls and Graying Populations, October 2009

2831 Klaus Wälde, Production Technologies in Stochastic Continuous Time Models, October 2009

2832 Biswa Bhattacharyay, Dennis Dlugosch, Benedikt Kolb, Kajal Lahiri, Irshat Mukhametov and Gernot Nerb, Early Warning System for Economic and Financial Risks in Kazakhstan, October 2009

2833 Jean-Claude Trichet, The ECB's Enhanced Credit Support, October 2009

2834 Hans Gersbach, Campaigns, Political Mobility, and Communication, October 2009

2835 Ansgar Belke, Gunther Schnabl and Holger Zemanek, Real Convergence, Capital Flows, and Competitiveness in Central and Eastern Europe, October 2009 
2836 Bruno S. Frey, Simon Luechinger and Alois Stutzer, The Life Satisfaction Approach to Environmental Valuation, October 2009

2837 Christoph Böhringer and Knut Einar Rosendahl, Green Serves the Dirtiest: On the Interaction between Black and Green Quotas, October 2009

2838 Katarina Keller, Panu Poutvaara and Andreas Wagener, Does Military Draft Discourage Enrollment in Higher Education? Evidence from OECD Countries, October 2009

2839 Giovanni Cespa and Xavier Vives, Dynamic Trading and Asset Prices: Keynes vs. Hayek, October 2009

2840 Jan Boone and Jan C. van Ours, Why is there a Spike in the Job Finding Rate at Benefit Exhaustion?, October 2009

2841 Andreas Knabe, Steffen Rätzel and Stephan L. Thomsen, Right-Wing Extremism and the Well-Being of Immigrants, October 2009

2842 Andrea Weber and Christine Zulehner, Competition and Gender Prejudice: Are Discriminatory Employers Doomed to Fail?, November 2009

2843 Hadi Salehi Esfahani, Kamiar Mohaddes and M. Hashem Pesaran, Oil Exports and the Iranian Economy, November 2009

2844 Ruediger Bachmann and Christian Bayer, Firm-Specific Productivity Risk over the Business Cycle: Facts and Aggregate Implications, November 2009

2845 Guglielmo Maria Caporale, Burcu Erdogan and Vladimir Kuzin, Testing for Convergence in Stock Markets: A Non-Linear Factor Approach, November 2009

2846 Michèle Belot and Jan Fidrmuc, Anthropometry of Love - Height and Gender Asymmetries in Interethnic Marriages, November 2009

2847 Volker Nitsch and Nikolaus Wolf, Tear Down this Wall: On the Persistence of Borders in Trade, November 2009

2848 Jan K. Brueckner and Stef Proost, Carve-Outs Under Airline Antitrust Immunity, November 2009

2849 Margarita Katsimi and Vassilis Sarantides, The Impact of Fiscal Policy on Profits, November 2009

2850 Scott Alan Carson, The Relationship between Stature and Insolation: Evidence from Soldiers and Prisoners, November 2009

2851 Horst Raff and Joachim Wagner, Intra-Industry Adjustment to Import Competition: Theory and Application to the German Clothing Industry, November 2009

2852 Erkki Koskela, Impacts of Labor Taxation with Perfectly and Imperfectly Competitive Labor Markets under Flexible Outsourcing, November 2009 
2853 Cletus C. Coughlin and Dennis Novy, Is the International Border Effect Larger than the Domestic Border Effect? Evidence from U.S. Trade, November 2009

2854 Johannes Becker and Clemens Fuest, Source versus Residence Based Taxation with International Mergers and Acquisitions, November 2009

2855 Andreas Hoffmann and Gunther Schnabl, A Vicious Cycle of Manias, Crashes and Asymmetric Policy Responses - An Overinvestment View, November 2009

2856 Xavier Vives, Strategic Supply Function Competition with Private Information, November 2009

2857 M. Hashem Pesaran and Paolo Zaffaroni, Optimality and Diversifiability of Mean Variance and Arbitrage Pricing Portfolios, November 2009

2858 Davide Sala, Philipp J.H. Schröder and Erdal Yalcin, Market Access through Bound Tariffs, November 2009

2859 Ben J. Heijdra and Pim Heijnen, Environmental Policy and the Macroeconomy under Shallow-Lake Dynamics, November 2009

2860 Enrico Spolaore, National Borders, Conflict and Peace, November 2009

2861 Nina Czernich, Oliver Falck, Tobias Kretschmer and Ludger Woessmann, Broadband Infrastructure and Economic Growth, December 2009

2862 Evžen Kočenda and Martin Vojtek, Default Predictors and Credit Scoring Models for Retail Banking, December 2009

2863 Christian Gollier and Martin L. Weitzman, How Should the Distant Future be Discounted when Discount Rates are Uncertain?, December 2009

2864 Tiberiu Dragu and Mattias Polborn, Terrorism Prevention and Electoral Accountability, December 2009

2865 Torfinn Harding and Beata Smarzynska Javorcik, A Touch of Sophistication: FDI and Unit Values of Exports, December 2009

2866 Matthias Dischinger and Nadine Riedel, There's no Place like Home: The Profitability Gap between Headquarters and their Foreign Subsidiaries, December 2009

2867 Andreas Haufler and Frank Stähler, Tax Competition in a Simple Model with Heterogeneous Firms: How Larger Markets Reduce Profit Taxes, December 2009

2868 Steinar Holden, Do Choices Affect Preferences? Some Doubts and New Evidence, December 2009

2869 Alberto Asquer, On the many Ways Europeanization Matters: The Implementation of the Water Reform in Italy (1994-2006), December 2009 
2870 Choudhry Tanveer Shehzad and Jakob De Haan, Financial Reform and Banking Crises, December 2009

2871 Annette Alstadsæter and Hans Henrik Sievertsen, The Consumption Value of Higher Education, December 2009

2872 Chris van Klaveren, Bernard van Praag and Henriette Maassen van den Brink, Collective Labor Supply of Native Dutch and Immigrant Households in the Netherlands, December 2009

2873 Burkhard Heer and Alfred Maußner, Computation of Business-Cycle Models with the Generalized Schur Method, December 2009

2874 Carlo Carraro, Enrica De Cian and Massimo Tavoni, Human Capital Formation and Global Warming Mitigation: Evidence from an Integrated Assessment Model, December 2009

2875 André Grimaud, Gilles Lafforgue and Bertrand Magné, Climate Change Mitigation Options and Directed Technical Change: A Decentralized Equilibrium Analysis, December 2009

2876 Angel de la Fuente, A Mixed Splicing Procedure for Economic Time Series, December 2009

2877 Martin Schlotter, Guido Schwerdt and Ludger Woessmann, Econometric Methods for Causal Evaluation of Education Policies and Practices: A Non-Technical Guide, December 2009

2878 Mathias Dolls, Clemens Fuest and Andreas Peichl, Automatic Stabilizers and Economic Crisis: US vs. Europe, December 2009

2879 Tom Karkinsky and Nadine Riedel, Corporate Taxation and the Choice of Patent Location within Multinational Firms, December 2009

2880 Kai A. Konrad, Florian Morath and Wieland Müller, Taxation and Market Power, December 2009

2881 Marko Koethenbuerger and Michael Stimmelmayr, Corporate Taxation and Corporate Governance, December 2009 